ABUD, K. M.; SILVA, A. C. M.; ALVES, R. C. Ensino de História. São

Paulo: Cengage Learning, 2010, 178p.

\title{
A HISTÓRIA, SUA ESCRITA E SEU ENSINO
}

Diogo da Silva Roiz ${ }^{1}$

O ensino de História tem voltado a estar em discussão. Por certo, suas discussões não se encerram, mas, de tempos em tempos, há maior envergadura dos debates. E, neste caso, entre 1996 e 2006, da discussão e aprovação da última LDB até as recentes deliberações sobre história e cultura africana e afro-brasileira, indígena e dos povos orientais, tais questões deram novo fôlego as discussões e questionamentos sobre a aplicação, ensino e reflexão sobre a História e sua escrita em sala de aula.

A publicação do interessante livro de Kátia Maria Abud, André Chaves de Melo Silva e Ronaldo Cardoso Alves, Ensino de História, além de estar inserido neste contexto, também demonstra como o tema em questão é promissor e tem gerado uma série de debates nos últimos anos. A proposta da obra é viabilizar um conjunto de técnicas e procedimentos, que sejam operacionais e adequados para o trabalho docente em sala de aula. Ao buscarem demonstrar a importância dos documentos escritos para o ensino de história, e por meio deles inserir o trabalho com jornais, obras literárias, letras de música, mapas, fotografias, cinema, cultura material e os espaços da

${ }^{1}$ Doutorando em História pela UFPR, bolsista do CNPq. Mestre em História pela Unesp, Campus de Franca. Professor dos cursos de História e de Ciências Sociais da Universidade Estadual de Mato Grosso do Sul (UEMS), na Unidade de Amambai. 
história nos museus, além de ser indicada a necessidade do estudo do meio, a obra nos oferece uma série de mecanismos para tornarem mais dinâmico o trabalho em sala de aula.

Sendo a Didática da História uma metodologia, uma prática e meios de favorecerem melhor oferecimento e apreensão do ensino de história, ela também "constitui-se em torno de um objeto diverso do objeto da História", por que se "esta investiga o passado e constrói um conhecimento próprio, a versão escolar ultrapassa a simples transmissão de saberes, para se tornar um campo de conhecimento no qual se imbricam a História ciência e a História escolar, cada uma com elementos próprios" (p. IX). Nesse aspecto, o "saber escolar seria constituído sobre a base do conhecimento histórico em conjunção com outros conhecimentos e nas relações com os saberes dos quais os alunos são portadores" ( $p . X$ ).

Se o "conceito de História como campo de conhecimento é fundamentalmente relacionado ao conceito de fontes históricas", para "proporcionar o desenvolvimento do pensamento histórico do aluno e fazê-lo distanciar-se do senso comum, a Didática da História propõe procedimentos críticos em relação às fontes, analisadas como recursos para a aprendizagem do aluno", quer dizer, "promove a utilização do raciocínio comparativo, da periodização do tempo histórico, distinto de um tempo subjetivo, da maestria do grau de generalização dos conceitos, distinguindo completamente a História de seus usos", e, para isso ser feito adequadamente, "mobiliza metodologias clássicas das ciências humanas e sociais: questionamento e observação, coleta de dados, exame e descrição e coloca em perspectiva os desdobramentos entre noções comuns e conceitos históricos" (p. XIII).

Por essa razão fazem um rápido panorama dos desenvolvimentos da escrita da história e da prática de seu ensino, conformada numa didática especial, entre o século XIX e o XX. De 
imediato, questionam-se sobre a importância das fontes para a pesquisa e para o ensino de história, demonstrando a diferença nos usos, leituras e interpretações, e o papel fundamental que tem para o ensino de História. Desse modo, em cada capítulo elaboram um rápido esboço da fonte e como foi tratada pela historiografia, como deve ser trabalhada em sala de aula, com sugestões de atividades e questões que podem ser feitas. O livro traz ainda quadros didáticos sobre tipologia de fontes, fragmentos de documentos e roteiros de análise de fontes, com as respectivas bibliografias especializadas, tratadas no capítulo, ao final de cada um, com rápidos comentários sobre cada uma das indicações.

Assim, o fazem quando tratam dos jornais e das publicações periódicas; quando discutem a literatura (tomando como exemplo o conto $O$ homem na multidão de Edgar Allan Poe); ao discutirem a função das letras de música para a aprendizagem da História; ao passarem para o estudo do meio (e mostrarem como a literatura e as letras de música podem contribuir para o seu aprendizado em sala de aula); ao o articularem com o estudo dos mapas, para que seja vislumbrada mudanças e permanências no território analisado; ao ser enfocada a cultura material, pois, sua utilização como "meio de construir conhecimento histórico não se esgota na análise dos artefatos [do passado], mas impõe aos historiadores a mesma abordagem em relação às suas etapas de confecção" (p. 112), e, em sala de aula, o "trabalho pedagógico [permite] desmistifica[r] a idéia de que os objetos só são importantes historicamente se pertencerem às classes dominantes no passado (visto que a maioria dos museus conserva apenas os objetos pertencentes à elite político-econômica das sociedade)" (p. 115); ao articularem esta análise com o estudo dos espaços da história fornecidos pelos museus, que "é fruto de uma série de forças e interesses que operaram na sua construção, instituição e manutenção" (p. 138); deles passarem para o estudo 
das fotografias, que "é uma rica fonte de informações para a reconstituição do passado, ainda que sua utilização também possa comportar a constituição de ficções" (p. 147); e, por fim, ao demonstrarem a importância do cinema em sala de aula, tendo em vista que "à semelhança do que ocorre com o conhecimento histórico, são produzidos com base em processos de pluralização de sentidos ou verdades", e, por isso, "as obras cinematográficas são construções carregadas de significados, construídos a partir da seleção de elementos que irão compor as imagens e o som que as acompanham e, depois, na articulação entre os diferentes conjuntos de imagens a partir da edição e montagem dos filmes" (p. 165).

Em todos os casos, de aplicação e usos de fontes em sala de aula, o livro fornece instrumentais seguros para que o professor de história possa alçar novos voos sobre o ensino de História e no trabalho com seus alunos. Donde ser uma referência para o tratamento de questões, que seguramente com as mudanças recentes da sociedade e operacionalizadas pelas políticas públicas no ensino de História, ainda se mantém em aberto, e sujeitas as mais variadas formas de tratamento e resolução. Por tudo isso, a obra chega em boa hora, ainda mais por se tratar de uma base de consulta extremamente atual.

Recebido em 02 de Outubro de 2012. Aprovado em 11 de Novembro de 2012. 